\title{
Purification and characterization of an extracellular $\beta$-lactamase produced by Acinetobacter calcoaceticus
}

\author{
Bernd Blechschmidt, Petra Borneleit* and Hans-Peter Kleber \\ Bereich Biochemie, Sektion Biowissenschaften, Universität Leipzig, Talstr. 33, 0-7010 Leipzig, \\ Federal Republic of Germany
}

(Received 16 January 1992; accepted 11 February 1992)

\begin{abstract}
A $\beta$-lactamase was purified 430-fold from the culture supernatant of Acinetobacter calcoaceticus by ion exchange chromatography on CM-Sephadex and affinity chromatography on phenylboronic-acid-agarose. The purified enzyme was homogeneous as judged by SDS-PAGE, and was characterized with respect to molecular mass ( 38 and $41 \mathrm{kDa}$ by gel filtration on Sephadex G-75 and SDS-PAGE, respectively), pH optimum (pH 7.0), temperature optimum $\left(45^{\circ} \mathrm{C}\right)$ and isoelectric point (9.3). The $\beta$-lactamase showed mainly cephalosporinase activity. It was inhibited by cloxacillin, carbenicillin, penicillanic acid sulphone (sulbactam) and aztreonam. It was not inhibited by clavulanic acid up to a concentration of $0.25 \mathrm{mM}$. Neither EDTA nor p-chlormercuribenzoate, up to concentrations of 1 or $100 \mathrm{mM}$, respectively, affected activity. According to these characteristics, it is a typical CEP-N cephalosporinase.
\end{abstract}

\section{Introduction}

Acinetobacter calcoaceticus is an increasingly important cause of nosocomial infection (Bergogne-Bérézin et al., 1987; Dijkshoorn et al., 1987a, b, 1989), and one of the particular attributes of isolated strains is resistance to many antimicrobial agents, including $\beta$-lactam antibiotics. The resistance of these strains against $\beta$-lactams probably results from the production of $\beta$-lactamases (Joly-Guillou et al., 1987, 1988). Joly-Guillou et al. (1988) screened one hundred clinical isolates of $A$. calcoaceticus for enzymic resistance to $\beta$-lactam antibiotics, and showed that $81 \%$ of the strains produced a $\beta$-lactamase. They observed penicillinases of the TEM and CARB type and also cephalosporinase activity.

TEM and CARB enzymes are plasmid-encoded and well-characterized (Medeiros, 1984). The exact nature and character of the presumed chromosomal cephalosporinases of Acinetobacter spp. is not fully clarified (JolyGuillou et al., 1987, 1988; Joly-Guillou \& BergogneBérézin, 1986; Hood \& Amyes, 1989, 1991). There is general agreement that they belong to the Group 1 enzymes (CEP-N) of the classification of Bush (1989 a) i.e., they are cephalosporinases not inhibited by clavulanic acid.

However, upon closer examination, Hood \& Amyes

*Author for correspondence.
(1991) found considerable heterogeneity among the Acinetobacter cephalosporinases. On the basis of isoelectric focusing, molecular mass and biochemical properties, they described four different Acinetobacter Chromosomal Enzymes (ACEs) with molecular masses of up to $1000 \mathrm{kDa}$, and they envisaged an even more complex situation when all genospecies of Acinetobacter were investigated.

Furthermore, conflicting views exist with respect to the inducibility of these enzymes. Morohoshi \& Saito (1977) and Medeiros (1984) found the chromosomal $\beta$ lactamases of $A$. anitratum to be inducible enzymes, whereas Bauernfeind (1986) described them as either inducible or constitutive. For all eight strains investigated by Hood \& Amyes (1991) no induction was observed with cefoxitin as the inducer.

A wild-type $A$. calcoaceticus strain CCM 5593 was previously reported to be resistant to a great variety of penicillins and cephalosporins and to produce a cephalosporinase (Blechschmidt et al. 1989). The enzyme could be induced by various $\beta$-lactams, including ampicillin and imipenem. Best results with respect to enzyme yield were obtained with the inducer cefotaxime and long (24 h) cultivation times (Blechschmidt et al., 1991). Under conditions of maximum enzyme production, more than $90 \%$ of the enzyme was found in the culture medium. This extracellular location is not due to cell lysis or periplasmic leakage, but could be attributed to a semi- 
selective export process across the outer cell membrane (Borneleit et al., 1991). However, there might be another type of $\beta$-lactamase which is not inducible and which is retained within the cells.

In view of the multiple $\beta$-lactamases observed in Acinetobacter this study was performed to characterize and classify the $\beta$-lactamase exported into the extracellular medium by A. calcoaceticus CCM 5593.

\section{Methods}

Micro-organism. Acinetobacter calcoaceticus CCM 5593 was obtained from the Czechoslovak Collection of Micro-organisms, Brno, Czechoslovakia and used throughout this study.

Antibiotics. Antibiotics were obtained from commercial suppliers as follows: cephalosporin $\mathrm{C}$, cephaloridine, carbenicillin, nafcillin, oxacillin, cloxacillin and cefuroxime from Sigma; penicillin $G$ and cefalexin from Jenapharm; cefotiam (Halospor) and cefsulodine (Monaspor) from Ciba-Geigy; cephalothin from Eli Lilly; amoxycillin (Amoxypen) from Grünenthal; ampicillin from Serva; azlocillin (Securopen) from Bayer; cefotaxime (Claforan) from Hoechst; aztreonam from ICN. Clavulanic acid was used as a component of Augmentan (clavulanic acid/amoxycillin in a molar ratio of $1: 2$ ) (Smith Kline Beecham)

Culture conditions. A. calcoaceticus CCM 5593 was stored on nutrient agar I (Immunpräparate) at $4^{\circ} \mathrm{C}$. For $\beta$-lactamase production, a minimal salts medium (Kleber et al., 1973) with $1 \%(\mathrm{w} / \mathrm{v})$ sodium acetate, supplemented with $0.5 \%$ yeast extract was used. Cultivation was carried out in $500 \mathrm{ml}$ Erlenmayer flasks containing $100 \mathrm{ml}$ medium. An induction culture was prepared by making a $1: 25$ dilution of an overnight culture in fresh medium and incubating it at $30^{\circ} \mathrm{C}$ with shaking. Cefotaxime $\left(50 \mu \mathrm{g} \mathrm{ml}^{-1}\right)$ was added as inducer immediately after inoculation of the culture. After $24 \mathrm{~h}$ cultivation, the cells were harvested by centrifugation at $5000 \mathrm{~g}$ for $15 \mathrm{~min}$ at $4{ }^{\circ} \mathrm{C}$.

Determination of $\beta$-lactamase activity. $\beta$-Lactamase activity was determined by a spectrophotometric method (Samuni, 1975; Waley, 1974) measuring the decrease in absorbance at an appropriate wavelength, and with a substrate concentration of $480 \mu \mathrm{M}$ at $20^{\circ} \mathrm{C}$ (Specord M42; Carl Zeiss). The wavelength used was that which gave a maximum in the difference spectrum when a non-hydrolysed substrate was scanned against a hydrolysed one. The millimolar absorbancy difference was used to calculate the rate of hydrolysis. One unit of enzyme activity $(\mathrm{U})$ is defined as the amount of enzyme that hydrolysed $1 \mu \mathrm{mol}$ substrate in $1 \mathrm{~min}$ at $20^{\circ} \mathrm{C}$ in $100 \mathrm{~mm}$-potassium phosphate buffer, $\mathrm{pH} \mathbf{7 \cdot 0 .}$.

Effects of temperature and $p H$ on $\beta$-lactamase activity. Thermal stability and temperature optimum were determined in $100 \mathrm{~mm}$ potassium phosphate buffer, $\mathrm{pH} 7 \cdot 0$. To investigate $\mathrm{pH}$ dependence, a $50 \mathrm{~mm}$-glycylglycine/piperazine buffer (pH 4-10) was used. Activity was determined by the macro-iodometric assay of Perret (1954) with cefalexin $(480 \mu \mathrm{M})$ as substrate.

Purification of $\beta$-lactamase. Cell-free culture medium was dialysed against $20 \mathrm{~mm}$-glycylglycine/piperazine buffer (pH 8.0) or $16 \mathrm{~h}$ at $4{ }^{\circ} \mathrm{C}$. Then CM-Sephadex C-50 gel [ $\left.10 \mathrm{~g}(1 \text { medium })^{-1}\right]$ was added and the mixture was stirred carefully. After $90 \mathrm{~min}$, the gel was removed by filtration, washed with buffer and packed into a column $(20 \times 2.5 \mathrm{~cm})$. The column was eluted with a 0 to $1 \mathrm{M}$ linear gradient of $\mathrm{NaCl}$ in
$20 \mathrm{~mm}$-glycylglycine/piperazine buffer, $\mathrm{pH} 8 \cdot 0$. Fractions $(4 \mathrm{ml})$ were collected and assayed for $\beta$-lactamase activity. $\beta$-Lactamase positive fractions were pooled, concentrated to $10 \mathrm{ml}$ by pressure filtration (Amicon PM 10 filter) and dialysed against $20 \mathrm{mM}$-triethanolamine hydrochloride $(\mathrm{pH} 7 \cdot 0)$ containing $1 \mathrm{M}-\mathrm{NaCl}$ for $16 \mathrm{~h}$ at $4{ }^{\circ} \mathrm{C}$.

For affinity chromatography, a boronic acid column with a hydrophilic spacer arm was prepared according to Cartwright \& Waley (1984). The gel was washed with $200 \mathrm{ml} \mathrm{NaCl} /$ sorbitol $(1 \mathrm{M} / 0.5 \mathrm{M} ; \mathrm{pH}$ 7.0 ), $200 \mathrm{ml} 0.5 \mathrm{M}$-sodium borate (pH 7.0) and finally $20 \mathrm{~mm}$-triethanolamine hydrochloride (pH 7.0) containing $1 \mathrm{M}-\mathrm{NaCl}$ (loading buffer). Enzyme preparation was applied to the column and run at a flow rate of $30 \mathrm{ml} \mathrm{h}^{-1}$. The column was washed with loading buffer until the $A_{280}$ of washings was zero. The $\beta$-lactamase was eluted with $0.5 \mathrm{M}$-sodium borate ( $\mathrm{pH} \mathrm{7.0)}$ ) containing $1 \mathrm{M}-\mathrm{NaCl}$. For further use, $\beta$ lactamase was lyophilized and stored at $-15^{\circ} \mathrm{C}$.

Determination of $K_{m}$ and $V_{\max }$. In order to calculate $K_{\mathrm{m}}$ and $V_{\max }$, enzyme activities were measured in duplicate over a range of different substrate concentrations at different wavelengths: cephalothin (from $8-480 \mu \mathrm{M} ; \lambda=263.3 \mathrm{~nm}$ ), cephalosporin $\mathrm{C}$ (from 8 to $480 \mu \mathrm{M}$; $\lambda=263 \mathrm{~nm}$ ), cefalexin (from 8 to $480 \mu \mathrm{M} ; \lambda=262.5 \mathrm{~nm}$ ), cephaloridine (from 8 to $440 \mu \mathrm{M} ; \lambda=259.8 \mathrm{~nm}$ ), cefotiam (from 8 to $480 \mu \mathrm{M}$; $\lambda=276 \mathrm{~nm}$ ), penicillin $\mathrm{G}$ (from 1 to $240 \mu \mathrm{M} ; \lambda=233 \mathrm{~nm}$ ), ampicillin (from 1 to $240 \mu \mathrm{M} ; \lambda=235 \mathrm{~nm}$ ), amoxycillin (from 1 to $240 \mu \mathrm{M}$; $\lambda=243.2 \mathrm{~nm}$ ) and azlocillin (from 1 to $240 \mu \mathrm{M} ; \lambda=231.5 \mathrm{~nm}$ ). The reaction was started by adding enzyme to the substrate, which had been preincubated in $100 \mathrm{~mm}$-potassium phosphate buffer, $\mathrm{pH} 7.0$. Change of absorbance was recorded for $2 \mathrm{~min}$ to calculate the initial rate of hydrolysis at $20^{\circ} \mathrm{C}$.

Protein determination. Protein content was determined by the Lowry method with bovine serum albumin as the standard.

\section{Results}

\section{Purification of $\beta$-lactamase}

The $\beta$-lactamase liberated into the culture medium by Acinetobacter calcoaceticus CCM 5593 could be purified by a two-step procedure (Table 1). After dialysis of the cell-free culture supernatant against $0.02 \mathrm{M}$-glycylglycine/piperazine buffer ( $\mathrm{pH} \mathrm{8.5),} \mathrm{within} 90 \mathrm{~min} 80-90 \%$ of the enzyme bound to CM Sephadex C-50. After elution by a linear salt gradient the enzyme was purified 78-fold. A final purification of about five-fold was achieved by an affinity chromatography step using $\mathrm{m}^{-}$ aminophenylboronic-acid-hemisulphate-modified AffiGel 10. The purified enzyme had a specific activity of $104.9 \mathrm{U}$ (mg protein $)^{-1}$ and was homogeneous according to SDS-PAGE (Fig. 1).

\section{Molecular mass and isoelectric point}

The molecular mass of the purified $\beta$-lactamase was estimated to be $38 \mathrm{kDa}$ by Sephadex G-75 gel filtration, and $41 \mathrm{kDa}$ by SDS-PAGE (Fig. 1). The isoelectric point was $9 \cdot 3$ (Fig. 2). 


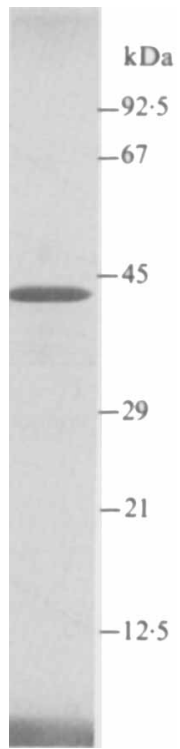

Fig. 1. SDS-PAGE and molecular mass determination for purified $\beta$-lactamase. $25 \mu \mathrm{g}$ protein was dissolved in SDS $\left(2 \%, \mathrm{w} / \mathrm{v} ; 100^{\circ} \mathrm{C}\right.$, $10 \mathrm{~min}$ ). Electrophoresis was done using the Laemmli (1970) buffer system in $12.5 \%(\mathrm{w} / \mathrm{v})$ polyacrylamide slab gels. Protein was stained with Coomassie Blue G-250. Molecular mass markers were phosphorylase B $(92.5 \mathrm{kDa})$, bovine serum albumin $(67 \mathrm{kDa})$, hen egg ovalbumin ( $45 \mathrm{kDa}$ ), carbonic anhydrase $(29 \mathrm{kDa})$, trypsin inhibitor (soya bean) $(21 \mathrm{kDa})$ and cytochrome $c(13 \mathrm{kDa})$.

\section{Effect of temperature and $\mathrm{pH}$ on the activity of the enzyme}

Activity and stability at $\mathrm{pH} 7.0$ were measured at different temperatures between 20 and $60^{\circ} \mathrm{C}$. The apparent temperature optimum was $45^{\circ} \mathrm{C}$. When the enzyme was incubated for $30 \mathrm{~min}$ at $55^{\circ} \mathrm{C}, 70 \%$ of the activity determined after incubation at $45^{\circ} \mathrm{C}$ was recovered.

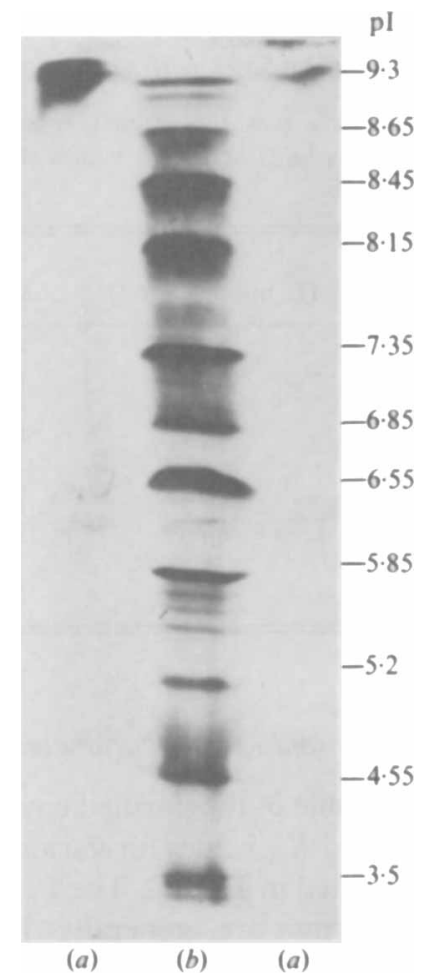

Fig. 2. Isoelectric focusing of $\beta$-lactamase. (a) $\beta$-lactamase (1 and $0 \cdot 25 \mu \mathrm{g})$ and $(b)$ standard marker proteins $(5 \mu \mathrm{g})$. Isoelectric focusing was performed in Phastgel (IEF 3-9) using the Phastsystem (Pharmacia). For separation and silver-staining, computer programs (Dombach, 1989) were used. Marker proteins (pI 3-10; Pharmacia): amyloglucosidase (3.5), trypsin inhibitor (soya bean) (4.55), $\beta$-lactoglobulin A (5.2), carbonic anhydrase B (bovine) (5.85), carbonic anhydrase B (human) (6.55), myoglobin, acid band (horse) (6.85), myoglobin, basic band (horse) (7.35), lectin, acid band (Lens culinaris) $(8 \cdot 15)$, lectin, medium band $(L$. culinaris) $(8 \cdot 45)$, lectin, basic band (L. culinaris) (8.65), trypsinogen (9.3).

The $\mathrm{pH}$ optimum was $7 \cdot 0$. The $\beta$-lactamase was inactive with cefalexin as the substrate at $\mathrm{pH}$ values below $4 \cdot 3$.

Table 1. Purification of the extracellular $\beta$-lactamase from A. calcoaceticus CCM 5593

Values are related to a volume of 2.51 culture supernatant. $\beta$-Lactamase activity was determined spectrophotometrically with cefalexin ( $480 \mu \mathrm{M})$ as substrate.

\begin{tabular}{|c|c|c|c|c|c|}
\hline Step & $\begin{array}{l}\text { Protein } \\
\text { (mg) }\end{array}$ & $\begin{array}{c}\text { Total activity } \\
\text { (U) }\end{array}$ & $\begin{array}{l}\text { Specific activity } \\
\left(\mathrm{U} \mathrm{mg}^{-1}\right)\end{array}$ & $\begin{array}{c}\text { Yield } \\
(\%)\end{array}$ & $\begin{array}{l}\text { Purification } \\
\quad(- \text { fold })^{*}\end{array}$ \\
\hline 1. Cell-free culture medium & 8653 & 1610 & $0 \cdot 186$ & 100 & - \\
\hline 2. Dialysis & 6357 & 1550 & $0 \cdot 244$ & 96 & 1 \\
\hline $\begin{array}{l}\text { 3. CM-Sephadex C-50- } \\
\text { Batch (pH 8.5) }\end{array}$ & $60 \cdot 2$ & 1143 & $19 \cdot 0$ & 71 & 78 \\
\hline $\begin{array}{l}\text { 4. } m \text {-Aminophenhlboronic- } \\
\text { acid-hemisulphate- } \\
\text { modified Affi-Gel } 10\end{array}$ & $9 \cdot 4$ & 987 & 104.9 & 61 & 430 \\
\hline
\end{tabular}

* Purification factors were related to dialysed culture supernatant because the yeast extract contained in the medium caused artificially high values in protein determination. 
Table 2. Kinetic parameters of the $\beta$-lactamase from A. calcoaceticus CCM 5593 with various $\beta$-lactam substrates

$\beta$-Lactamase activity was determined spectrophotometrically. Michaelis constants $\left(K_{m}\right)$ and $V_{\max }$ values were determined by Eadie-Hofstee plots.

\begin{tabular}{|c|c|c|c|}
\hline Substrate & $\left.\frac{V_{\max }}{(\mathrm{U} \text { mg protein }}{ }^{-1}\right)$ & $K_{\mathrm{m}}(\mu \mathrm{M})$ & $V_{\max } / K_{\mathrm{m}}$ \\
\hline Cephalothin & $655 \cdot 0$ & $267 \cdot 1$ & 2.45 \\
\hline Cephalosporin C & $341 \cdot 2$ & $288 \cdot 4$ & $1 \cdot 18$ \\
\hline Cefalexin & $191 \cdot 5$ & $399 \cdot 7$ & 0.48 \\
\hline Cephaloridine & $79 \cdot 3$ & $204 \cdot 6$ & 0.39 \\
\hline Cefotiam & 23.5 & $94 \cdot 6$ & 0.25 \\
\hline Penicillin G & $18 \cdot 7$ & $3 \cdot 1$ & 6.04 \\
\hline Ampicillin & $4 \cdot 0$ & $8 \cdot 7$ & 0.46 \\
\hline Amoxycillin & $5 \cdot 7$ & 14.4 & 0.39 \\
\hline Azlocillin & $2 \cdot 7$ & 14.6 & $0 \cdot 14$ \\
\hline
\end{tabular}

\section{Substrate specifity and kinetic parameters}

The substrate profile of the purified enzyme is represented by the $V_{\max }$ and $K_{\mathrm{m}}$ values for various cephalosporins and penicillins listed in Table 2 . The $V_{\max }$ values indicate that cephalosporins are generally hydrolysed more quickly than penicillins. For the newer cephalosporins cefsulodine and cefuroroxime, no activity was determined. The same was found for the penicillins nafcillin, carbenicillin, oxacillin and cloxacillin. Cephalothin was hydrolysed best of the cephalosporins, and penicillin G, best of the penicillins. For the cephalosporins tested up to $550 \mu \mathrm{M}$, no substrate inhibition was observed.

The $K_{\mathrm{m}}$ values reveal a higher affinity of penicillins for the enzyme than that of the cephalosporins. Furthermore, the ratio $V_{\max } / K_{\mathrm{m}}$ indicates that under physiological conditions (no substrate saturation of the enzyme) penicillins are hydrolysed comparably to cephalosporins. The best substrate under these conditions should be penicillin G.

\section{$\beta$-Lactamase inhibition}

Both cloxacillin and carbenicillin were effective in inhibiting the hydrolysis of the most susceptible substrate cephalothin. The inhibitor constants estimated by Dixon plots were $K_{\mathrm{i}}=0.074 \mu \mathrm{M}$ for cloxacillin and $K_{\mathrm{i}}=0.135 \mu \mathrm{M}$ for carbenicillin (Fig. 3). In the corresponding Lineweaver-Burk plots (not shown) an intercept of the regression lines at the ordinate indicated competitive inhibition.

Sulbactam exerts its inhibitory effect in a progressive manner. A preincubation time of the enzyme with the inhibitor of about $180 \mathrm{~min}$ is needed to reach the full extent of inhibition (Fig. 4). From the initial rates obtained after this period an $I_{50}$ value of $116 \mathrm{nM}$ was determined.
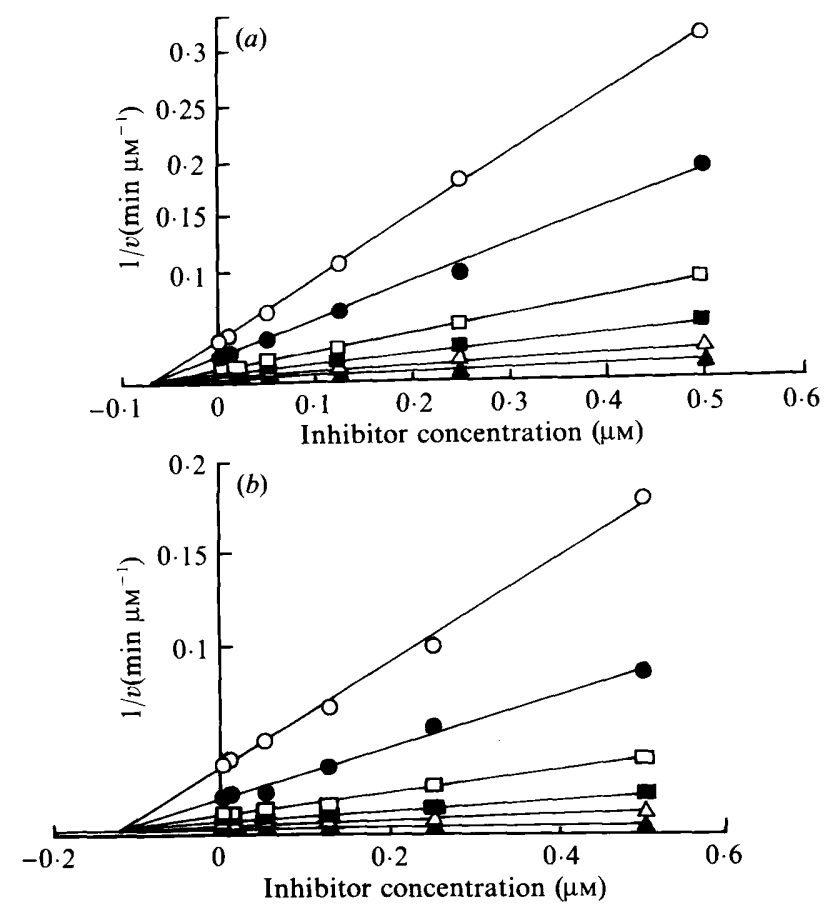

Fig. 3. Inhibition of cephalothin hydrolysis by cloxacillin $(a)$ and carbenicillin (b) (Dixon plots). Substrate concentrations: $\bigcirc, 15 \mu \mathrm{M} ; \bullet$, $30 \mu \mathrm{M} ; \square, 60 \mu \mathrm{M} ; 120 \mu \mathrm{M} ; \triangle, 240 \mu \mathrm{M}$; and $\triangle, 480 \mu \mathrm{M}$. $\beta$-Lactamase was assayed spectrophotometrically. Initial rates plotted were derived after a 1 min preincubation of the enzyme with substrate and inhibitor. A linear reaction course was obtained for a further $5 \mathrm{~min}$ recording period.

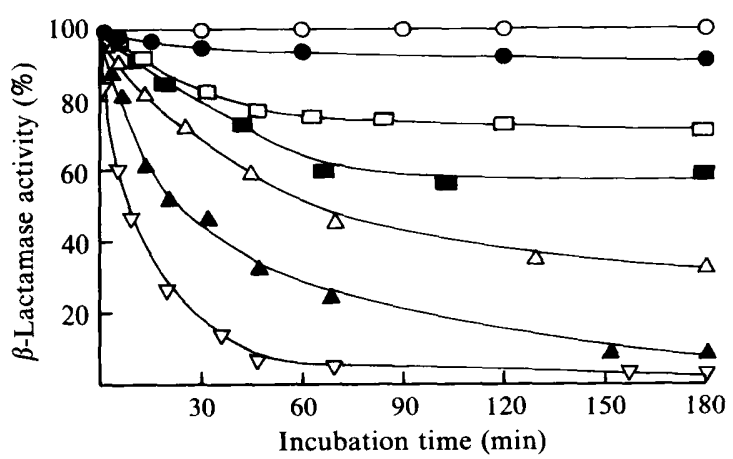

Fig. 4. Inhibition of cephalothin hydrolysis by sulbactam. $\beta$-Lactamase $\left(0.01 \mathrm{mg} \mathrm{ml}^{-1}\right)$ was incubated with sulbactam at different concentrations: $0,0 \mathrm{nM} ; \bullet, 10 \mathrm{nM} ; \square, 50 \mathrm{nM} ; \square, 100 \mathrm{nM} ; \triangle, 200 \mathrm{nM} ; \Delta$, $400 \mathrm{nM}$; and $\nabla, 800 \mathrm{nM}$. At times indicated, samples were withdrawn and $\beta$-lactamase activity was assayed spectrophotometrically (substrate: cephalothin, $480 \mu \mathrm{M})$.

The inhibitory effect of aztreonam on cephalothin hydrolysis was fully established only after a preincubation period of $10 \mathrm{~min}$. Under these conditions, $I_{50}$ was $2.0 \mu \mathrm{M}$. 
Neither p-chlormercuribenzoate (pCMB) $(0 \cdot 1-$ $100 \mathrm{~mm})$ nor EDTA $(0.05-1 \mathrm{~mm})$ had a significant inhibitory effect on the purified $\beta$-lactamase.

Clavulanic acid at concentrations between 5 and $250 \mu \mathrm{M}$ did not inhibit amoxycillin hydrolysis.

\section{Discussion}

We purified and characterized a cephalosporinase produced as an extracellular enzyme by $A$. calcoaceticus CCM 5593. For the purification procedure, the key step was affinity chromatography on $m$-amino-phenylboronic-acid-hemisulphate-modified Affi-Gel 10 . Cartwright \& Waley (1984) found a perfect correlation between a $\beta$-lactamase being inhibited by boronic acids and its retention on boronic acid columns, supplementing the correlation between a $\beta$-lactamase being a serine enzyme and its inhibition by boronic acids. This suggests that the $\beta$-lactamase of $A$. calcoaceticus CCM 5593 may be regarded as a serine enzyme, and this characterization is supported by the fact that it is not inhibited by EDTA, which excludes the possibility of a metalloenzyme.

The $\beta$-lactamase from $A$. calcoaceticus CCM 5593 hydrolyses cephalosporins better than penicillins and therefore is to be designated a cephalosporinase. $\beta$ Lactamases of class I according to the Richmond \& Sykes (1973) classification (R\&S I $\beta$-lactamases) are also commonly referred to as cephalosporinases, since hydrolysis rates $\left(V_{\text {max }}\right)$ are often much larger for cephalosporins than for penicillins. However, this is rather a misnomer, since these enzymes, like the enzyme of $A$. calcoaceticus CCM 5593, are capable of hydrolysing certain penicillins with high efficiency $\left(V_{\max } / K_{\mathrm{m}}\right)($ Richmond \& Sykes, 1973). Even the more detailed examination of the substrate specificity of the enzyme purified from A. calcoaceticus CCM 5593 is in accordance with several reports for other R\&S I enzymes, e.g. from Enterobacter cloacae, Pseudomonas aeruginosa, Citrobacter freundii, Morganella morganii (Sanders \& Sanders, 1986), Escherichia coli (Sawai et al., 1982), Proteus rettgeri (Ohya et al., 1980) and Serratia marcescens (Yang et al., 1990).

For the Acinetobacter cephalosporinase, the kinetics of hydrolysis for various $\beta$-lactam antibiotics have been described by Morohoshi \& Saito (1977) and, subsequently, for some newer agents by Hikida et al. (1989). On the basis of these data, together with the inhibitor studies performed by these authors it was classified by Bush $(1989 b)$ in Group 1, subtitled CEP-N. Group 1 cephalosporinases correlate primarily with the Sykes \& Richmond classes Ia, Ib, and Id. They are almost exclusively chromosomally encoded and are often inducible. They are potently inhibited by cloxacillin and aztreonam but poorly inhibited by clavulanic acid or sulbactam.

All these characteristics apply for the A. calcoaceticus CCM 5593 cephalosporinase with the exception of sulbactam inhibition. Similarly, Joly-Guillou et al. (1988) found inhibition by cloxacillin and sulbactam and resistance to clavulanic acid for various Acinetobacter strains which exhibited cephalosporinase activity only. However, while sulbactam sensitivity suggests a group $2 \mathrm{e}$ enzyme according to Bush (1989c), these enzymes are usually inhibited by pCMB. Furthermore, sulbactam inhibition $\left(K_{\mathrm{i}} 3.8 \mu \mathrm{M}\right)$ was also reported for the Group 1 enzyme from Citrobacter freundii GN 7391 (Bush $1989 c$ ).

The Group 1 enzymes usually have basic isoelectric points and molecular masses greater than $30 \mathrm{kDa}$. JolyGuillou et al. (1987) described 30 strains of Acinetobacter with a chromosomal cephalosporinase of $\mathrm{pI}>8$. For 14 strains investigated by Medeiros et al. (1985), the pI ranged from 8.8 to $>10$. Among the 8 strains investigated by Hood \& Amyes (1991), seven partially purified cephalosporinases did not focus on conventional isoelectric focusing systems, which was attributed to extremely basic isoelectric points together with exceptionally high molecular masses, which were found to be $>1000 \mathrm{kDa}$. Our data are more similar to the parameters reported by Morohoshi \& Saito (1977) who determined a molar mass of $30 \mathrm{kDa}$, an optimal temperature of $40^{\circ} \mathrm{C}$ and an optimal pH 7.25-7.50.

On the basis of their characterization of the cephalosporinases from 8 strains belonging to 3 different genospecies, Hood \& Amyes (1991) postulated 4 different Acinetobacter Chromosomal Enzyme (ACE) subgroups, all of them belonging to the general group $1 \beta$ lactamases. Among them, the subgroup 3 enzyme from A. Iwoffii $\mathrm{H} 126$ closely resembled the enzyme investigated in this study. A molecular mass of $32500 \mathrm{Da}$, a pI of $9 \cdot 1$, and a $K_{\mathrm{m}}$ for cephaloridine of $380 \mu \mathrm{M}$ agree fairly well with our results. The $I_{50}$ values for cloxacillin and aztreonam ( 0.003 and $0.08 \mu \mathrm{M}$, respectively) are lower than those found for the A. calcoaceticus CCM 5593 enzyme. However, Hood \& Amyes (1991) have already pointed out that the degree of heterogeneity among the Acinetobacter cephalosporinases might turn out to be even higher when the full spectrum of the 17 genospecies was investigated.

The authors acknowledge the financial support of the BMFT (project number 0319886A6) and would like to thank Janett Leischnig for expert technical assistance.

\section{References}

BaUernfeind, A. (1986) Classification of beta-lactamases. Reviews of Infectious Diseases 8 (Suppl.), 470-481. 
Bergogne-Bérézin, E., Joly-Guillou, M. L. \& Vieu, J. F. (1987). Epidemiology of nosocomial infections due to Acinetobacter calcoaceticus. Journal of Hospital Infection 10,105-113.

Blechischmidt, B., Borneleit, P., Emanouilidis, I., Lehmann, W. \& KLEBER, H.-P. (1989). Extracellular location of a $\beta$-lactamase produced by Acinetobacter calcoaceticus. Applied Microbiology and Biotechnology 32, 85-89.

BLECHSCHMIDT, B., BORNELEIT, P. \& KLEBER, H.-P. (1991). Influence of cultivation and induction conditions on $\beta$-lactamase production in Acinetobacter calcoaceticus. Applied Microbiology and Biotechnology 36, 364-368.

Borneleit, P., Blechschmidt, B., Eschrich, K. \& Kleber, H.-P. (1991). $\beta$-Lactamase export across the outer membrane of Acinetobacter calcoaceticus: perturbation of the outer membrane lipopoly saccharide leaflet by enzyme overproduction. Archives of Microbiology 155, 500-504.

BUsh, K. $(1989 a)$. Characterization of $\beta$-lactamases. Antimicrobial Agents and Chemotherapy 33, 259-263.

BusH, K. (1989b). Classification of $\beta$-lactamases: Groups 1, 2a, 2b, and 2b'. Antimicrobial Agents and Chemotherapy 33, 264-270.

BUSH, K. (1989c). Classification of $\beta$-lactamases: Groups $2 c, 2 d, 2 e, 3$, and 4. Antimicrobial Agents and Chemotherapy 33, 271-276.

Cartwright, S. J. \& Waley, S. G. (1984). Purifications of $\beta$ lactamases by affinity chromatography on phenylboronic acidagarose. Biochemical Journal 221, 505-512.

Dijkshoorn, L., Michel, M. F. \& Degener, J. E. (1987a). Cell envelope protein profiles of Acinetobacter calcoaceticus strains isolated in hospitals. Journal of Medical Microbiology 23, 313-319.

Dijkshoorn, L., Van Vianen, W., Degener, J. E. \& Michel, M. F. (1987b). Typing of Acinetobacter calcoacoticus strains isolated from hospital patients by cell envelope protein profiles. Epidemiology and Infection 99, 659-667.

Dijkshoorn, L., Wubbels, J. L., Beunders, A. J., Degener, J. E., BoKs, A. L. \& MicheL, M. F. (1989). Use of protein profiles to identify Acinetobacter calcoaceticus in a respiratory care unit. Journal of Clinical Pathology 42, 853-857.

DoмвaCH, G. (1989). Isolierung und Charakterisierung einer Hydantoinase aus Arthrobacter sp. DSM 3747. Dissertation, TU Braunschweig.

Hikida, M., Yoshida, M., Mitsuhashi, S. \& Inoue, M. (1989). Purification and properties of a cephalosporinase from Acinetobacter calcoaceticus. Journal of Antibiotics 42, 123-126.

Hood, J. \& AmYes, S. G. B. (1989). A novel method for the identification and distinction of the $\beta$-lactamases of the genus Acinetobacter. Journal of Applied Bacteriology 67, 157-163.

HOOD, J. \& AMYES, S. G. B. (1991). The chromosomal $\beta$-lactamases of the genus Acinetobacter: enzymes which challenge our imagination. In The Biology of Acinetobacter, pp. 117-132. Edited by K. J. Towner, E. Bergogne-Bérézin \& C. A. Fewson. New York: Plenum Press.

Joly-Guillou, M. L. \& Bergogne-Bérézin, E. (1986). Distribution of beta-lactamases in clinical strains of Acinetobacter calcoaceticus. 26th Interscience Conference on Antimicrobial Agents and Chemotherapy, New Orleans, Louisiana. Abstract 202.

Joly-Guillou, M. L., Bergogne-Bérézin, E. \& Moreau, N. (1987). Enzymatic resistance to beta-lactams and amino-glycosides in Acinetobacter calcoaceticus. Journal of Antimicrobial Chemotherapy 20 $771-782$

Joly-Guillou, M. L., Vallee, E., Bergogne-Bérézin, E. \& Phillipon, A. (1988). Distribution of beta-lactamases and phenotype analysis in clinical strains of Acinetobacter calcoaceticus. Journal of Antimicrobial Chemotherapy 22, 597-604.

KLEBER, H.-P., SCHÖPP, W. \& AURICH, H. (1973). Verwertung von n-Alkanen durch einen Stamm von Acinetobacter calcoaceticus. Zeitschrift für Allgemeine Mikrobiologie 13, 455-477.

LaEmmLI, U. K. (1970). Cleavage of structural proteins during the assembly of the head of bacteriophage T4. Nature, London 227, 680 685.

MedeIros, A. A. (1984). $\beta$-Lactamases. British Medical Bulletin 40, 18 27.

Medeiros, A. A., Hare, R., Papa, E., Adam, C. \& Miller, G. H. (1985). Gram-negative bacilli resistant to third generation cephalosporins: $\beta$-lactamase characterisation and susceptibility to $\mathrm{SCH}$ 34343. Journal of Antimicrobial Chemotherapy 15, 119-124.

MoroHoshi, T. \& SAITo, T. (1977). Beta-lactamase and beta-lactam antibiotic resistance in Acinetobacter anitratus (syn. A. calcoaceticus). Journal of Antibiotics 30, 969-973.

Ohya, S., Fuji-Kuriyama, Y., Yamamoto, M. \& Sugawara, S. (1980). Purification and some properties of $\beta$-lactamases from Proteus rettgeri and Proteus insconstans. Microbiology and Immunology 24, 815-824.

Perrett, C. J. (1954). Iodometric assay of $\beta$-lactamase. Nature, London 174, 1012.

Richmond, M. H. \& SyKes, R. B. (1973). The $\beta$-lactamases of Gramnegative bacteria and their possible physiological role. Advances in Microbial Physiology 9, 31-88.

Samuni, A. (1975). A direct spectrophotometric assay and determinations of Michaelis constants for the $\beta$-lactamase reaction. Analytical Biochemistry 63, 17-26.

SANDers, C. C. \& Sanders, W. E., JR (1986). Type I $\beta$-lactamases of Gram-negative bacteria: Interaction with $\beta$-lactam antibiotics. Journal of Infectious Diseases 154, 792-800.

SawaI, T., KanNo, M. \& TsuKamoto, K. (1982). Characterization of eight beta-lactamases of Gram-negative bacteria. Journal of Bacteriology 152, 567-571.

WALEY, S. G. (1974). A spectrophotometric assay of $\beta$-lactamase action on penicillins. Biochemical Journal 139, 159-163.

YANG, Y., Wu, P. \& Livermore, D. M. (1990). Biochemical characterization of a $\beta$-lactamase that hydrolyzes penems and carbapenems from two Serratia marcescens isolates. Antimicrobial Agents and Chemotherapy 34, 755-758. 